\title{
Dekolonialisasi: Menuju pembebasan materi pembelajaran Sejarah di Indonesia abad 21
}

\author{
Gita Lorensia Dannari, Maria Ulfa, Lutfiah Ayundasari* \\ Universitas Negeri Malang, Jl. Semarang No. 5 Malang, Jawa Timur, Indonesia \\ *Penulis korespondensi, Surel: lutfiah.fis@um.ac.id
}

Paper received: 01-04-2021; revised: 15-04-2021; accepted: 30-04-2021

\begin{abstract}
To foster a sense of Indonesian youthful nationalism, the materials presented in history learning in schools are always decolonized, as a form of retaliation against colonial historiography which is only seen from a colonial point of view. However, the material taught in learning in schools is also the same, only different from the point of view used. According to the author, this is not the right step to be used in fostering a sense of nationalism in the younger generation, because history must be viewed as neutral, presented as it is, so that there is no mutual revenge in writing history. Therefore, it is necessary to have decolonization in history learning. The purpose of writing this article is to describe the forms of decolonization and their impact on learning history in Indonesia. Based on the impact of writing history that is too Indonesian centric, but does not have a significant impact in cultivating a sense of nationalism for the younger generation, it is necessary to have a decolonialization effort in learning history. The research method used in writing this article is the library method.
\end{abstract}

Keywords: decolonialization; Indonesian center; Historical learning

\begin{abstract}
Abstrak
Untuk menumbuhkan rasa nasionalisme generasi muda Indonesia, maka materi-materi yang disajikan dalam pembelajaran sejarah di sekolah selalu bersifat dekolonisasi, sebagai bentuk pembalasan terhadap historiografi kolonial yang hanya dilihat dari sudut pandang kolonial. Akan tetapi, materi-materi yang diajarkan dalam pembelajaran di sekolah juga bersifat sama, hanya berbeda pada sudut pandang yang digunakan. Hal tersebut menurut penulis bukanlah langkah yang tepat untuk digunakan dalam menumbuhkan rasa nasionalisme generasi muda, karena sejarah harus dipandang netral, disajikan apa adanya, sehingga tidak timbul sikap saling balasdendam dalam menulis sejarah. Oleh karena itu, diperlukan adanya dekolonialisasi dalam pembelajaran sejarah. Adapun tujuan penulisan artikel ini, yaitu untuk menguraikan bentuk-bentuk dekolonisasi dan dampaknya dalam pembelajaran sejarah di Indonesia. Berdasarkan pada dampak dari penulisan sejarah yang terlalu Indonesiasentris, tetapi tidak memberikan dampak signifikan dalam penanaman rasa nasionalisme generasi muda maka diperlukan adanya upaya dekolonialisasi dalam pembelajaran sejarah. Adapun metode penelitian yang digunakan dalam penulisan artikel ini yaitu metode kepustakaan.
\end{abstract}

Kata kunci: dekolonialisasi; Indonesiasenteris; pembelajaran Sejarah

\section{Pendahuluan}

Melalui pembelajaran sejarah peserta didik diharapkan dapat bijaksana dalam kehidupan sehari-harinya. Dengan mempelajari peristiwa-peristiwa masa lampau dapat dijadikan acuan dalam bertindak, sehingga terbentuklah sikap yang bijaksana dari peserta didik. Tujuan dari pembelajaran sejarah sendiri menurut Sayono (2013) dan Sirnayatin (2017) adalah agar peserta didik dapat memperoleh hikmah dari peristiwa-peristiwa pada masa lampau. Peserta didik dapat menemukan hakikat dari perkembangan budaya dan peradaban manusia, sehingga dapat diterapkan dalam kehidupan sehari-hari. Melalui pembelajaran sejarah peserta didik dapat memahami bahwa masa lalu memiliki peran penting untuk 
kemajuan di masa depan. Dari penjelasan tersebut dapat dikatakan bahwa pembelajaran sejarah ini bertujuan untuk menyampaikan nilai-nilai penting dari peristiwa masa lampau kepada peserta didik, untuk menumbuhkan kesadaran sejarah. Namun dalam sajian materi pembelajaran pada buku-buku paket di sekolah, selalu dipolitisasi, sehingga peristiwa sejarah yang disajikan tersebut tidak bersifat netral, tetapi terlalu keIndonesiaan atau dekolonisasi yaitu memandang peristiwa sejarah hanya dari sudut pandang Indonesia.

Mohammad Ali (1995) dalam Mudzakkir (2015) mengatakan bahwa "banyak orang menganggap dekolonisasi adalah persoalan bekas negeri jajahan. Dekolonisasi ini dianggap sebagai proses yang dilakukan oleh bekas bangsa terjajah untuk keluar dari warisan struktural dan kultural yang ditinggalkan oleh bekas bangsa penjajahnya. Dalam proses itu, penilaian moral yang dualistik sering mengemuka. Bangsa penjajah adalah jahat, sementara bangsa terjajah adalah baik. Dekolonisasi membalik begitu saja posisi-posisi sebelumnya yang dibangun oleh narasi kolonial. Historiografi Indonesiasentris yang berusaha dibangun sejak Seminar Sejarah Nasional I 1957 berkembang dalam kesadaran seperti ini". Historiografi yang bersifat dekolonisasi ini kemudian berdampak pada materi pembelajaran sejarah di sekolah, karena historiografi menjadi sumber dalam penyusunan materi pembelajaran sejarah, sehingga materi pembelajaran sejarah di sekolah juga bukanlah sajian peristiwa masa lampau yang disusun apa adanya. Tujuan penyampaian materi sejarah yang bersifat Indonesia Sentris atau dekolonisasi yaitu untuk menumbuhkan rasa nasionalisme peserta didik. Akan tetapi hal ini justru membuat materi pembelajaran sejarah yang disampaikan kepada peserta didik bukan lagi sejarah yang riil. Padahal dengan menyajikan sejarah yang riil kepada peserta didik, seperti sejarah kontroversial juga dapat menumbuhkan rasa nasionalisme peserta didik.

Berdasarkan paparan di atas maka, diperlukan suatu upaya dekolonialisasi dalam materi pembelajaran sejarah di sekolah, sehingga dapat dilakukan penyampaian sejarah yang bebas dan tidak terikat (apa adanya) kepada peserta didik. Dekolonialisasi sendiri menurut Lauterboom (2019) adalah suatu pendekatan yang tidak lepas dari kajian mengenai suatu kolonialisme dan imperialisme. Dalam kajiannya, dekolonialisasi ini lebih bersifat sebagai pembebasan dalam memandang suatu peristiwa kolonialisme dan imperialisme, jika dalam kajian sejarah berarti tidak bersifat seperti historiografi Kolonialsentris dan Indonesiasentris tetapi lebih bebas, yaitu menyajikan sejarah sebagaimana adanya seperti yang terjadi di lapangan. Sejarah yang dihadirkan bukan hanya sejarah orang-orang besar tetapi juga orangorang kecil dalam suatu masyarakat. Selain itu, dengan menyajikan peristiwa sejarah yang tidak menonjolkan sikap Indonesiasentris, seperti sejarah-sejarah kontroversial tidak akan merusak moral bangsa. Seperti yang dikatakan oleh Saefudin, Hariyono \& Sariyatun (2013) bahwa pada dasarnya pembelajaran sejarah bertujuan untuk menyampaikan pelajaran dan makna dari peristiwa yang telah terjadi di masa lalu. Oleh karena itu, materi pembelajaran sejarah yang disampaikan secara bijaksana dan sesuai dengan kebenaran yang ada, dapat menciptakan masyarakat yang sadar akan sejarah. Serta, berdampak pada pola pikir masyarakat dalam kebijaksanaannya menanggapi peristiwa sejarah yang kontroversial.

\section{Metode}

Dalam penyusunan artikel ini, penulis menggunakan metode penelitian kepustakaan yang didasarkan pada pengumpulan informasi yang dibutuhkan dalam penulisan artikel dari berbagai buku dan jurnal yang didapatkan secara offline atau di perpustakaan langsung maupun secara online. Informasi yang telah didapatkan tersebut kemudian dianalisis untuk dijadikan sebagai sumber referensi dalam penulisan artikel ini. Sari \& Asmendri (2020) 
mengatakan bahwa metode penelitian kepustakaan merupakan suatu metode penelitian yang berbasis pada pemanfaatan koleksi-koleksi perpustakaan, seperti buku, artikel, catatan dan koleksi lainnya, yang dapat digunakan sebagai sumber data dan informasi dalam suatu penelitian. Metode penelitian kepustakaan juga menggunakan langkah-langkah yang sistematis agar hasil penelitian lebih maksimal. Terdapat tiga langkah utama dalam penelitian kepustakaan yaitu kegiatan mengumpulkan data, kemudian mengelola data yang telah dikumpulkan dan yang terakhir yaitu menarik kesimpulan dari informasi yang telah dikumpulkan dan dianalisis.

\section{Hasil dan Pembahasan}

\subsection{Dekolonisasi Dalam Pembelajaran Sejarah di Indonesia}

Menurut Kamus Besar Bahasa Indonesia, dekolonisasi merupakan penghapusan daerah jajahan, mengembalikan kekuasaan pemerintahan kepada daerah jajahan dan memerdekakan daerah jajahan. Dalam artian lain dekolonisasi adalah pemberian kemerdekaan politik kepada daerah jajahan atau koloni. Penghapusan daerah jajahan di Indonesia disebabkan oleh aktifnya negara Indonesia yang termasuk anggota PBB mengusahakan kemerdekaan wilayahnya. Selain itu Indonesia juga aktif dalam organisasi-organisasi regional dan internasional.

Semangat dekolonisasi terlihat ketika lahirnya gerakan-gerakan nasionalis di Indonesia. Gerakan nasionalis ini ada jauh sebelum Indonesia merdeka. Dalam pembelajaran sejarah Indonesia, adanya gerakan nasionalis dilatarbelakangi oleh hasrat kemajuan dan kesetaraan bangsa Indonesia khususnya pemuda yang telah mengecap bangku sekolah baik di dalam maupun luar negeri (Abdullah \& Lapian, 2012). Selain dilatarbelakangi oleh hasrat kesetaraan, juga disebabkan oleh kebijakan politik etis atau kebijakan balas budi terhadap pribumi. Tentunya ini menguntungkan bagi masyarakat pribumi karena dengan adanya kebijakan ini, pribumi bisa bebas mempelajari apapun sehingga lahirlah tokoh-tokoh perjuangan. Tokohtokoh ini lahir dari kaum bangsawan yang cerdas dan berpikiran terbuka. Para tokoh tersebut kemudian berinisiatif membuat organisasi-organisasi modern. Maka lahirlah Budi Oetomo (BO), Indische Partij (IP), Sarekat Islam (SI), dll yang semuanya memiliki tujuan untuk kesejahteraan rakyat Indonesia dan lepas dari cengkraman belenggu kaum Belanda.

Setelah berpuluh-puluh tahun Indonesia dijajah oleh bangsa Belanda, pada tahun 1942 Belanda menyerah kepada Jepang dan kekuasaan atas Indonesia beralih ke Dai Nippon. Dalam pembelajaran sejarah Indonesia diulas tentang masuknya Jepang ke Indonesia, organisasiorganisasi pada masa pendudukan Jepang, kebijakan Jepang yang menindas rakyat sampai janji kemerdekaan dan pembentukan panitia kemerdekaan atau yang selanjutnya disebut PPKI. Dalam tanda kutip, pembelajaran sejarah hanya dilihatkan sisi putih bangsa Indonesia yang terjadi di masa lalu, padahal dibalik materi-materi tersebut, proses dekolonisasi Indonesia dimulai pada saat pendudukan Jepang tahun 1942-1945. Selama periode ini, ribuan orang Belanda di Indonesia dipenjara, sementara sebagian lainnya terpaksa berusaha bermigrasi ke Australia, Amerika Serikat, dan Belanda (Mudzakkir, 2015). Pada masa pendudukan Jepang ini, para pemuda menerima banyak pelatihan militer seperti Seinendan, Keibodan, Peta, dan lainnya. Dalam artian Jepang saat itu menanamkan gerakan anti kolonialisme yang dibentuk dengan warna militer guna untuk kepentingan Perang Asia Timur Raya. Namun, menghasilkan luaran berupa sikap anti imperialisme. Sikap anti imperialisme ini 
nantinya berlanjut hingga kemerdekaan Indonesia atau masa bersiap. Dan ini, tidak dipaparkan dalam pembelajaran sejarah.

Masa bersiap terjadi setelah proklamasi kemerdekaan Indonesia atau pada saat Belanda kembali ke Indonesia pada agresi militer I. Saat itu bangsa Belanda yang bebas dari cengkraman Jepang karena Jepang takluk oleh sekutu, merasa keluar dari neraka dan jumawa terhadap orang-orang non Belanda. Dalam buku Indonesia Dalem Api dan Bara dijelaskan bahwa saking terlalu sombongnya orang Belanda, sampai-sampai mengeluarkan perkataan yang menyinggung orang-orang Pribumi seperti ejekan "vuile Inlander" atau "pribumi kotor" (Berdoeri, 2004). Hal inilah yang menjadi pemantik rasa kekesalan pribumi kepada orang asing. Setelah ejekan-ejekan tersebut, masyarakat pribumi mulai melakukan balas dendam. Pribumi yang dulu tertindas, kini sudah berani melawan dan bergerak dalam laskar-laskar yang membela revolusi. Pemboikotan dilakukan oleh pribumi kepada Belanda mulai dari lampu dan air diputus, dan tidak diperbolehkan menjual apapun kepada Belanda.

Kekacauan kembali memuncak pada tahun 1945 hingga 1946 karena pemerintahan Indonesia belum efektif. Terdapat berbagai hal yang tidak manusiawi di berbagai sudut kota seperti penjarahan, pembakaran, penganiayaan, pemerkosaan, dan pembunuhan. Oknum dari tindakan brutal ini yaitu pribumi dibawah payung laskar rakyat dan berdalih demi keamanan dan pertahanan kemerdekaan Indonesia. Tindakan criminal ini terus-terusan terjadi di berbagai kota, dan yang paling menonjol terdapat di daerah Jawa dan Sumatra. Di Jawa saja misalnya, terdapat tindakan pengosongan kota dan pembakaran atau bumi hangus yang digelarkan oleh pribumi. Menurut Gert, diperkirakan jumlah korban orang Eropa yang dibunuh pada masa bersiap ini sekitar 3.500 sampai 20.000 orang (Oostindie, 2016). Dari kekacauan peristiwa tersebut, terlihat banyak tindakan brutal yang dilakukan oleh pribumi bergulir terus menerus dan sulit untuk dicegah. Hingga akhirnya, terdapat istilah revolusi yang terlewat batas karena banyak memakan korban dan tidak pandang bulu untuk menghabisi nyawa orangorang Eropa.

Dalam pembelajaran sejarah Indonesia, cenderung menampilkan orang-orang Belanda yang destruktif dan merugikan rakyat, hal ini dikarenakan pribumi dijajah berpuluh-puluh tahun dan banyak ditindas oleh bangsa Belanda. Penindasan ini menjadi semacam trauma rakyat Indonesia kepada bangsa asing. Kemudian muncullah suatu historiografi indonesiasentris yang rasis, karena memandang bangsa Belanda adalah tokoh antagonis dan rakyat pribumi adalah tokoh protagonis. Ini senada dengan yang disampaikan oleh Bambang Purwanto (2006) historiografi indonesiasentris dalam konteks kekinian gagal menangkap kompleksitas dalam pertarungan politik identitas Indonesia kekinian. Akhirnya dalam pembelajaran sejarah, tidak pernah ditampilkan sisi gelap atau kejahatan pribumi.

\subsection{Dampak Dekolonisasi Terhadap Pembelajaran Sejarah}

Penulisan sejarah di Indonesia atau yang selanjutnya disebut historiografi dimulai sejak berlakunya historiografi kolonial yang dimulai sejak datangnya Eropa di tanah Hindia Belanda pada abad XVI-XX. Dalam perspektif historiografi kolonial, kolonial ditempatkan sebagai pelaku utama dalam penulisan tersebut, sedangkan pribumi dijadikan peran pembantu bahkan peran antagonis. Orang Eropa dianggap sebagai pahlawan karena telah berhasil menumpas pemberontakan dari orang-orang pribumi. Pribumi yang sedang berusaha mempertahankan 
tanahnya dianggap sebagai pemberontak dan gerakanya dipandang sebagai gerakan kaum ekstremis dari inlanders (Sulistiyono, 2016).

Selanjutnya, setelah proklamasi kemerdekaan pada tanggal 17 Agustus 1945, para sejarawan Indonesia berbondong-bondong membenahi penulisan sejarah Indonesia yang bercorak kolonial. Sama halnya dengan historiografi kolonial, historiografi Indonesia atau yang selanjutnya disebut historiografi Indonesiasentris lebih mengedepankan pribumi dan menjadikan pribumi sebagai pelaku utama dalam penulisan sejarah. Historiografi Indonesiasentris ini lebih menonjolkan semangat nasionalisme dan kepahlawanan. Adanya penulisan sejarah Indonesia yang bercorak indonesia sentris ini merupakan hal yang lumrah dilakukan pasca kemerdekaan karena sebagai bentuk legitimasi dan perlindungan dalam menghadapi kolonialisme Belanda yang belum sepenuhnya keluar dari Indonesia. Maka lahirlah sejarawan seperti Sartono Kartodirdjo yang mempelopori pendekatan ilmu sosial dalam historiografi Indonesiasentris (Kartodirdjo, 1982).

Dibalik dekolonisasi terhadap berbagai historiografi diatas, terdapat kekurangan yang berdampak bagi pembelajaran sejarah. Bambang Purwanto mengkritik bahwa historiografi yang terlalu Indonesiasentris menimbulkan semangat nasionalisme yang berlebihan sehingga menimbulkan anakronisme dalam menggambarkan periode kolonial. Seperti yang diketahui historiografi Indonesiasentris secara substantif sama dengan historiografi kolonial yaitu mengunggulkan etnis yang ditulis dari perspektif masing-masing. Pun nasionalisme yang diusung dekolonisasi ini keliru dari awal, karena menurut Bambang Purwanto dekolonisasi ini membangun wacana sekaligus perspektif yang menjadikan historiografi Indonesiasentris sekadar sebagai alat penghujat dan menggunakan masalalu sebagai tameng pembenaran (Purwanto, 2006). Oleh karena itu, dekolonisasi yang diusung hanya membenarkan bangsa pribumi dan mencemooh kolonial.

Seiring perkembangan zaman, nasionalisme saat ini sudah tidak bisa diromantisasi lagi. Romantisasi nasionalisme yang dilakukan pasca kemerdekaan sebagai sarana pemancing semangat bangsa Indonesia yang telah terjajah dan sudah berpuluh-puluh tahun menderita. Berbeda dengan zaman dahulu, sekarang di abad 21 romantisme pengusiran penjajah bukan lagi hal yang dibutuhkan. Bangsa Indonesia memerlukan nasionalisme yang berbeda karena masalah yang dihadapi di abad ini semakin kompleks. Tampaknya pendekatan historiografi Indonesiasentris lebih cocok digunakan untuk menjelaskan era Indonesia pra kemerdekaan. Namun, setelah merdeka pembelajaran sejarah lebih memerlukan historiografi yang netral demi menjawab masalah yang dihadapi sekarang.

Dampak lainnya dari dekolonisasi yaitu pembelajaran sejarah hanya dijadikan sebagai suatu kajian masa lampau sehingga terkesan tidak ada kaitannya dengan zaman sekarang dan tidak dapat menjawab persoalan-persoalan kekinian. Seperti yang diketahui, masalah-masalah yang terjadi di Indonesia seperti kemiskinan, ketidakadilan, ketergantungan, dan eksploitasi. Pembelajaran sejarah diharapkan dapat menjawab masalah-masalah tersebut. Maka, perlu adanya suatu penulisan yang netral dan tidak berpihak dalam pembelajaran sejarah. Penulisan yang netral diperlukan agar topik-topik terkait masalah kekinian yang terjadi di masa lampau berani diangkat dan diajarkan dalam pembelajaran sejarah. Akhirnya, sejarah tidak hanya dipandang sebagai ilmu yang hanya bicara masa lampau tanpa ada kaitannya dengan masa yang akan datang (Sulistiyono, 2016). 
Memang, dewasa ini perlu adanya suatu pemahaman yang terbuka terkait pembelajaran sejarah di Indonesia. Siswa tidak hanya disuguhi oleh mindset sejarah hitam dan putih dimana putih adalah seorang pribumi yang rela menderita dan berjuang mati-matian untuk kemerdekaan. Kemudian ada juga pandangan bahwa kaum kiri adalah orang-orangyang penuh dosa karena terlibat dalam G30S dan sampai saat ini dalam pembelajaran sejarah, orang kiri menjadi tersangka utama atas pembunuhan para jenderal. Benar, bahwa sejarah ditulis oleh pemenang yang berkuasa. Namun, dalam pembelajaran sejarah juga tidak benar apabila hanya menampilkan hitam dan putih karena nantinya akan berpengaruh pada pandangan siswa. Alangkah lebih baiknya, jika menampilkan suatu penulisan sejarah yang netral seperti saja materi awal kemerdekaan Indonesia yang berbagai golongan ikut andil dalam pembentukan tersebut. Seperti kata Prof. Ariel Heryanto dalam sebuah wawancara di medcom.id bahwa sejarah Indonesia menerima sumbangan dari berbagai ragam pihak. Tidak hanya yang kiri atau hanya yang kanan. Kalau kemarin saya fokuskan pembicaraan pada yang kiri dan dengan dimensi trans-nasional, karena kedua hal ini sudah terlalu lama terabaikan, tertindas, terhapus (Adnan, 2017). Penulisan sejarah yang netral penting supaya rasa nasionalisme yang terbentuk antar siswa tidak rasis, tidak saling menyalahkan dan senantiasa menjaga keutuhan Negara Indonesia bersama-sama.

\subsection{Dekolonialisasi Materi Pembelajaran Sejarah Di Indonesia Abad 21}

Telah dijelaskan diatas bahwa dalam buku-buku pelajaran sejarah di sekolah, materimateri pelajaran yang disampaikan terlalu bersifat Indonesia sentris, salah satunya yaitu mengenai gerakan anti imperialisme di Indonesia. Gerakan anti imperialisme merupakan suatu gerakan yang menentang praktik imperialisme yang terjadi di berbagai negara di dunia. Praktik imperialisme dan kolonialisme yang menyebabkan terjadinya kemiskinan, kelaparan, perbudakan, peperangan dan berbagai masalah lainnya di negara jajahan, mendorong munculnya gagasan anti imperialisme di berbagai negara di dunia terutama di negara-negara yang terdapat di benua Asia dan Afrika. Negara-negara timur ini merupakan negara yang menjadi target kolonialisme dan imperialisme bangsa Eropa sejak dimulainya penjelajahan samudra oleh bangsa-bangsa Eropa. Indonesia dan negara-negara Asia Tenggara lainnya tidak luput dari praktik kolonialisme dan imperialisme ini. Susanto (2016) mengatakan bahwa "kolonialisme dan imperialisme yang terjadi di negara-negara Asia Tenggara, mendorong munculnya gerakan anti imperialisme yang direalisasikan dengan gerakan-gerakan kemerdekaan".

Di Indonesia sendiri, gerakan anti Imperialisme tidak selesai begitu saja setelah proklamasi kemerdekaan Indonesia pada tahun 1995, tetapi terus berlanjut. Gerakan anti imperialisme di Indonesia semakin mengalami perkembangan hingga cenderung radikal. Hal ini dapat kita lihat, pada perilaku orang-orang Indonesia terhadap orang-orang Indo-Eropa (hasil perkawinan campuran antara ibu pribumi dengan pria Eropa) di Indonesia pasca kemerdekaan. Sugiarti (2020) mengatakan bahwa pada masa pasca kemerdekaan, sampai akhir tahun 1960-an orang Indo harus meninggalkan Indonesia, mereka terusir dari tanah kelahirannya. Bukan hanya orang Indo tetapi juga orang Eropa totok. Hal ini sebagai bentuk balas dendam bangsa Indonesia terhadap sikap orang-orang Eropa dan Indo-Eropa terhadap masyarakat pribumi, sebelum kemerdekaan Indonesia. Oleh karena itu, ketika maraknya gerakan anti imperialisme di Indonesia, orang Eropa dan Indo-Eropa ini terusir dari Indonesia dan bahkan sering pula terjadi kekerasan terhadap orang-orang Indo yang masih menetap di Indonesia. 
Namun, sejarah-sejarah Indonesia seperti sikap keras masyarakat Indonesia terhadap kaum Indo-Eropa dan Eropa ataupun kaum lainnya diluar golongan pribumi, saat maraknya gerakan anti kolonialisme di Indonesia tidak disajikan secara keseluruhan kepada generasi muda Indonesia melalui pembelajaran sejarah di kelas. Materi pembelajaran sejarah mengenai gerakan anti imperialisme yang disajikan di sekolah, seolah-olah menunjukkan bahwa tindakan bangsa Indonesia semuanya benar dan bangsa Eropa atau pihak imperialis ini selamanya jahat, padahal tidaklah demikian. Selain itu, pada awal kedatangan bangsa Barat ke Indonesia, materi sejarah menunjukkan bahwa bangsa Baratlah yang serakah, karena tujuan awalnya hanya berdagang tetapi kemudian berkembang menjadi penjajahan. Akan tetapi, ketika kita menganalisis peristiwa tersebut kita dapat menyadari bahwa pemerintahan kerajaan-kerajaan lokal di Indonesia saat itu dapat dimasuki oleh pihak penjajah karena pemerintahannya yang belum matang. Seandainya pemerintah kerajaan lokal saat itu tidak dengan mudah tertarik ketika ditawarkan sedikit keuntungan oleh bangsa Eropa kemungkinan kerajaan mereka tetap berdiri kokoh. Namun, seandainya Indonesia tidak pernah dijajah belum tentu akan ada Indonesia seperti saat ini. Oleh karena itu, peristiwa sejarah perlu dilihat secara netral untuk dijadikan pelajaran dalam pembangunan bangsa dan negara. Bukan hanya berupa materi sejarah yang terlalu Indonesiasentris.

Penulisan sejarah yang bersifat Indonesia Sentris ini dilakukan bertujuan untuk menanamkan rasa nasionalisme bagi generasi muda. Akan tetapi seperti yang kita lihat pada realita didalam masyarakat Indonesia saat ini, nilai-nilai budaya bangsa Indonesia bahkan semakin terkikis. Generasi muda semakin terbuka terhadap pengaruh asing melalui media massa, tetapi mulai pula melupakan jati dirinya sebagai bangsa Indonesia. Rusdiyani (2016) mengatakan bahwa "seiring dengan dinamika perkembangan politik, sosial, dan budaya di Indonesia peranan generasi muda mengalami pasang surut. Di zaman globalisasi sekarang peranan generasi muda terutama dalam mengimplementasikan Pancasila dalam kehidupan masyarakat menjadi semakin surut. Secara khusus persoalan generasi muda dengan eksistensi jiwa mudanya semakin meninggalkan nilai-nilai Pancasila. Pancasila tidak lagi menjadi landasan utama dalam bertindak dan berperilaku dari berbagai segi kehidupan generasi muda. Fenomena kecenderungan perilaku dan kepribadian generasi muda sekarang ini menunjukkan mulai hilangnya jati diri sebagai suatu individu yang berakar dari nilai-nilai luhur budaya bangsa. Kondisi faktual saat ini yang menggerus kepribadian generasi muda seperti: hilangnya identitas budaya bangsa, tawuran pelajar dan mahasiswa, narkoba, seks bebas, fenomena genk motor, kekerasan yang dilakukan generasi muda, dan degradasi moralitas pelajar." Hal ini menunjukkan bahwa usaha menanamkan nasionalisme melalui dekolonisasi materi pembelajaran sejarah tidaklah tepat. Tetapi justru membuat peristiwa sejarah semakin jauh dari kenyataan yang ada. Oleh karena itu, peristiwa sejarah perlu disampaikan apa adanya kepada peserta didik, agar apa yang telah terjadi di masa lalu dapat menjadi pelajaran untuk kedepannya. Sehingga, diperlukan adanya dekolonialisasi dalam pembelajaran sejarah.

\subsubsection{Pentingnya Dekolonialisasi Dalam Pembelajaran Sejarah}

Penyusunan buku-buku paket yang digunakan dalam pembelajaran sejarah di sekolah mengacu pada historiografi Indonesia yang bersifat Indonesia Sentris, seperti buku Sejarah Nasional Indonesia (SNI) dan buku-buku lainnya. Akan tetapi penulisan sejarah yang bersifat Indonesia Sentris dalam upaya memupuk rasa nasionalisme, kerap memunculkan perdebatan di antara berbagai pihak, karena penulisannya kerap melupakan sisi ilmiah dari sejarah. Seperti yang dikatakan oleh Kurniawati (2015) bahwa setelah proklamasi kemerdekaan 
Indonesia muncul gagasan untuk menempatkan Indonesia sebagai subjek dalam penulisan sejarah Indonesia atau Indonesiasentris. Penulisan sejarah Indonesiasentris ini sebagai pengganti dari sejarah yang ditulis oleh pihak kolonial yang menjadikan pihak kolonial sebagai subjeknya. Akan tetapi gagasan penulisan sejarah Indonesiasentris ini memunculkan perdebatan di antara sejarawan dan pemimpin Indonesia, mengenai bagaimana seharusnya sejarah Indonesia ini ditulisakan. Kemudian untuk membicarakan lebih lanjut mengenai penulisan sejarah Indonesia ini, maka diadakan kongres sejarah nasional pada tahun 1957. Namun, dalam kongres ini hanya membahas mengenai isu-isu filosofis dan teoritis. Oleh karena itu, historiografi Indonesia seolah-olah melupakan sisi ilmiah dari sejarah.

Penulisan sejarah yang seakan dipaksakan ke arah Indonesiasentris justru malah semakin mengaburkan fakta dari sejarah itu sendiri. Kurniawan (2017) mengatakan bahwa "sekalipun penulisan SNI yang sepintas mirip dengan buku babon Sejarah Hindia Belanda telah mencoba keras untuk keluar dari belenggu perspektif kolonial, namun gaya counter point of view dari sejarah kolonial masih kuat. Hal ini dikarenakan fokus penulisan masih kental diwarnai semangat gairah dekolonisasi sejarah untuk mengganti keberadaan buku teks Belanda. Akibatnya penulisan sejarah Indonesia yang terbentuk tak lebih dari sekedar Neertandosentrisme yang berganti subjek pelaku sejarah namun dengan konteks yang masih sama." Oleh karena itu, penyampaian sejarah yang bersifat Indonesiasentris ini tidak memberikan hasil yang memuaskan dalam menanamkan nasionalisme gerenasi muda, sehingga diperlukan adanya dekolonialisasi dalam penulisan sejarah terutama dalam pembelajaran sejarah di sekolah.

Sejarah merupakan salah satu matapelajaran yang sangat efektif dalam membangun karakter bangsa. Pernyataan tersebut sesuai dengan pendapat dari Sirnayatin, Ulhaq, Nuriah \& Winarsih (2017) bahwa sejarah merupakan salah satu mata pelajaran yang sangat penting, karena jati diri suatu bangsa dapat diperkenalkan kepada generasi mudanya melalui pembelajaran sejarah di sekolah. Melalui pembelajaran sejarah ini, diharapkan dapat menumbuhkan kesadaran sejarah bagi para peserta didik, karena peserta didik dapat mengampil nilai-nilai penting dari berbagai peristiwa yang telah terjadi dimasa lalu. Kemudian penerapan nilai-nilai yang telah diperoleh dari pembelajaran sejarah ini dapat menjadi acuan dalam bertindak, sehingga peserta didik sadar akan pentingnya masa lalu untuk membangun bangsa di masa depan. Oleh karena itu, perlu adanya dekolonialisasi dalam pembelajaran sejarah agar serangkaian peristiwa yang terjadi pada masa lampau ini dapat mendorong sifat kritis peserta didik dalam mengambil keputusan dalam kehidupan sehari-harinya maupun dimasa yang akan datang, agar kesalahan yang pernah terjadi di masa lampau tidak terjadi lagi.

Dekolonialisasi dalam materi pembelajaran sejarah di sekolah perlu untuk dilakukan. Hal ini bertujuan agar peristiwa sejarah yang disampaikan kepada peserta didik sesuai dengan peristiwa yang sebenarnya terjadi. Sehingga, ketika dihadapkan pada fakta sejarah yang sebenarnya masyarakat tidak lagi kaget dan bersedia menerima peristiwa sejarah ini sebagaimana adanya dan dijadikan pelajaran untuk tindakan di masa depan. Namun, penyampaian sejarah yang seperti ini menjadi tantangan bagi guru, agar materi ini dapat memberikan dampak positif dalam menanamkan jati diri bangsa Indonesia. Meskipun materi pada buku-buku pelajaran di sekolah masih bersifat dekolonisasi/Indonesiasentris, tetapi telah banyak tulisan-tulisan sejarah yang telah bersifat dekolonialisasi yang menyajikan sejarah apa adanya. Oleh karena itu, penyajian materi pembelajaran yang dekolonialisasi ini 
dapat dilakukan dengan memanfaatkan sumber belajar di luar buku-buku yang telah disediakan di sekolah.

Kurniawati (2015) mengatakan bahwa kurikulum 2013 sangat mendukung dalam penerapan pelajaran yang lebih menyenangkan terutama bagi peserta didik. Kurikulum 2013 ini, juga sangat mendukung kegiatan pembelajaran sejarah yang bersifat saintifik, yaitu peserta didik diajak untuk kritis dalam menemukan sumber belajar yang akan dijadikan sebagai referensi dalam mempermudah memahami peristiwa-peristiwa sejarah. Peserta didik dapat mengeksplorasi berbagai peristiwa sejarah yang tidak disajikan dalam sumber belajar yang telah disediakan di sekolah. Kegiatan pembelajaran yang lebih menyenangkan dan dapat membantu meningkatkan pemahaman peserta didik terhadap materi yang disampaikan, didukung oleh alokasi waktu pembelajaran sejarah yang lebih banyak, yaitu terdiri dari dua mata pelajaran yakni sejarah wajib dan sejarah peminatan. Alokasi waktu yang cukup banyak ini, dapat memberikan kesempatan kepada guru dalam mendesain kegiatan pembelajaran yang menyenangkan.

\subsubsection{Upaya Dekolonialisasi Pembelajaran Sejarah di Indonesia}

Ada berbagai strategi pembelajaran yang dapat digunakan dalam upaya dekolonialisasi pembelajaran sejarah. Dalam penyusunannya peran guru sangatlah penting dalam menentukan strategi tersebut. Semakin berkembangnya berbagai penulisan sejarah di Indonesia saat ini dapat dimanfaatkan oleh guru sebagai sumber dalam penyampaian pembelajaran kepada peserta didik, sehingga pembelajaran sejarah tidak hanya berfokus pada materi pelajaran yang terdapat di buku-buku paket yang telah disediakan di sekolah. Salah satu contoh strategi sederhana yang dapat diterapkan yaitu dengan menggunakan strategi pembelajaran kontekstual. Hasibuan (2014) mengatakan bahwa "strategi pembelajaran kontekstual (contekstual teaching and learning) adalah merupakan proses pembelajaran yang holistik dan bertujuan membantu siswa untuk memahami makna materi ajar dan mengaitkannya dengan konteks kehidupan mereka sehari-hari (konteks pribadi, sosial dan kultural), sehingga siswa memiliki pengetahuan/ keterampilan yang dinamis dan fleksibel untuk mengkonstruksi sendiri secara aktif pemahamannya." Strateg ini merupakan salah satu strategi yang dapat membantu agar siswa dapat memahami materi pembelajaran sejarah dengan muda, karena dihubungkan dengan kehidupan sehari-harinya.

Salah satu contoh kompetensi dasar yang dapat disajikan di kelas dengan menggunakan strategi pembelajaran kontekstual dalam upaya dekolonialisasi pembelajaran sejarah yaitu K.D 3.1 Menganalisis perubahan, dan keberlanjutan dalam peristiwa sejarah pada masa penjajahan asing hingga proklamasi kemerdekaan Indonesia. 4.1 Mengolah informasi tentang peristiwa sejarah pada masa penjajahan Bangsa Barat berdasarkan konsep perubahan dan keberlanjutan, dan menyajikannya dalam bentuk cerita sejarah. Melalui strategi pembelajaran kontekstual guru dapat mengajak peserta didik untuk melihat kembali dampak peristiwa kolonialisme dan imperialisme dalam kehidupan masyarakat Indonesia yang masih berlanjut saat ini, khususnya dalam kehidupan sehari-hari peserta didik. Salah satu contohnya yaitu modernisasi pendidikan di Indonesia, seandainya tidak ada kolonialisme dan imperialisme di Indonesia pada masa lalu, apakah masyarakat Indonesia dapat menerapkan pendidikan seperti saat ini?, dalam cara berpakaian, bahasa dan lain-lain, yang memberikan gambaran bahwa kolonialisme ini juga memberikan banyak dampak positif bagi Indonesia. Berikut ini rancangan 
RPP dengan strategi pembelajaran kontekstual dalam mewujudkan dekolonialisasi pembelajaran sejarah.

Tabel 1. Rencana Pelaksanaan Pembelajaran

\begin{tabular}{|c|c|c|}
\hline Kegiatan & Deskripsi Kegiatan Alokasi & $\begin{array}{l}\text { Alokasi } \\
\text { Waktu }\end{array}$ \\
\hline Pendahuluan & $\begin{array}{l}\text { Salam pembukaan dan doa untuk memulai kegiatan } \\
\text { pembelajaran. } \\
\text { Memeriksa kehadiran peserta didik. } \\
\text { Menyampaikan materi yang akan dibahas. } \\
\text { Mengajukan pertanyaan tentang hubungan materi } \\
\text { pertemuan sebelumnya dengan materi hari ini. } \\
\text { Menyampaikan tujuan pembelajaran. }\end{array}$ & 10 Menit \\
\hline Inti & $\begin{array}{l}\text { Guru menyampaikan materi mengenai perubahan, dan } \\
\text { keberlanjutan dalam peristiwa sejarah pada masa } \\
\text { penjajahan asing hingga proklamasi kemerdekaan } \\
\text { Indonesia, secara umum dalam pemerintahan Indonesia } \\
\text { baik yang bersifat positif maupun negatif. (Menggunakan } \\
\text { media pembelajaran berupa video ataupun gambar yang } \\
\text { menunjukkan adanya perubahan dan keberlanjutan). } \\
\text { Guru menyampaikan pembagian kelompok. } \\
\text { Peserta didik mencari informasi dan berdiskusi dengan } \\
\text { kelompok masing-masing mengenai perubahan dan } \\
\text { keberlanjutan peristiwa sejarah pada masa penjajahan } \\
\text { asing hingga proklamasi kemerdekaan yang masih } \\
\text { berpengaruh hingga saat ini dalam kehidupan sehari-hari } \\
\text { peserta didik, minimal } 5 \text { bentuk perubahan dan } \\
\text { keberlanjutan dalam setiap kelompok. } \\
\text { Peserta didik mempresentasikan hasil pencarian dan } \\
\text { diskusi kelompok. } \\
\text { Kemudian tanya jawab antara guru, kelompok dan audiens. }\end{array}$ & 70 Menit \\
\hline Penutup & $\begin{array}{l}\text { Guru melakukan evaluasi berupa memberikan pertanyaan- } \\
\text { pertanyaan kepada peserta didik untuk mengetahui } \\
\text { pemahaman peserta didik terhadap materi. } \\
\text { Refleksi dari salah satu peserta didik mengenai hal yang } \\
\text { didapatkan dari pelajaran hari ini. } \\
\text { Guru menyampaikan kesimpulan mengenai pembelajaran } \\
\text { hari ini. } \\
\text { Memberikan apresiasi dan motivasi kepada peserta didik, } \\
\text { salam penutup dan doa penutup. }\end{array}$ & 10 Menit \\
\hline
\end{tabular}

\section{Simpulan}

Dekolonisasi merupakan penghapusan suatu daerah jajahan. Dalam penulisannya, dekolonisasi cenderung ditulis dengan pendekatan historiografi Indonesiasentris. Historiografi Indonesiasentris lebih menonjolkan pribumi sebagai karakter utama dan tokoh protagonis dalam suatu cerita sejarah. Akibatnya, dalam pembelajaran sejarah Indonesia terkesan memberi kajian hitam dan putih kepada para siswa. Sebenarnya, historiografi Indonesiasentris cocok jika digunakan untuk membahas Indonesia pra kemerdekaan karena untuk menumbuhkan semangat kepahlawanan dan patriotisme. Namun, dalam perkembangannya dekolonisasi ini tidak dapat menjawab masalah kekinian dan menjadikan rasa nasionalisme yang berlebihan dan rasial. Maka, diperlukan suatu bentuk penulisan 
ataupun penyajian sejarah yang netral, apa adanya, dan tidak berpihak. Oleh karena itu, perlu adanya suatu dekolonialisasi dalam pembelajaran sejarah.

Dekolonialisasi pembelajaran sejarah dapat dilakukan dengan menyampaikan peristiwa sejarah secara netral kepada peserta didik. Namun, dalam mewujudkan dekolonialisasi pembelajaran sejarah peran guru sangatlah penting, karena terdapat juga berbagai peristiwa sejarah yang bersifat kontroversial sehingga guru harus dapat menyampaikannya dengan baik kepada peserta didik agar tidak terjadi kesalahpahaman. Selain itu, diperlukan pula bimbingan dari guru agar siswa dapat menemukan sumber-sumber sejarah yang dapat dipertanggungjawabkan dalam menjelaskan suatu peristiwa sejarah. Kurikulum yang diterapkan di Indonesia saat ini yakni kurikulum 2013 juga mendukung diwujudkannya dekolonialisasi pembelajaran sejarah ini, karena kesempatan pembelajaran sejarah menjadi bertambah khususnya untuk peserta didik jurusan IPS yaitu sejarah wajib dan sejarah peminatan.

\section{Daftar Rujukan}

Lapian, A. B., \& Lapian, A. B. (2012). Indonesia Dalam Arus Sejarah jilid 5 (Masa Pergerakan Kebangsaan). Jakarta: Ichtiar Baru van Hoeve.

Adnan, S. A. W. (2017). Wawancara Profesor Ariel Heryanto Sejarah Tidak Cuma Hitam-Putih. Medcom. Idhttps://www.medcom.id/pilar/interview/ybDMYjpk-sejarah-tidak-cuma-hitam-putih. Diakses pada tanggal 17 Mei 2021 pukul 9.31.

Hasibuan, M. I. (2014). Model Pembelajaran CTL (Contextual Teaching and Learning). Logaritma: Jurnal Ilmuilmu Pendidikan dan Sains, 2(01).

Kartodirdjo, S. (1982). Pemikiran dan perkembangan historiografi Indonesia: suatu alternatif. Jakarta: Gramedia.

Kurniawan, H. (2017). Pembelajaran Sejarah yang Indonesiasentris: Reformulasi Bahan Ajar Sejarah Berbasis Kebhinekaan. S. Margana, BahaUddin, \& A. Faisol (Eds.), Kapita Selekta (Pendidikan) Sejarah Indonesia, 204-221.

Kurniawati, K. (2015). Mencari Makna Dalam Sejarah: Meninjau Kembali Historiografi Indonesiasentris Sebagai Sumber Belajar Sejarah. Jurnal Pendidikan Sejarah, 4(2), 13-20.

Lauterboom, M. (2019). Dekolonialisasi Pendidikan Agama Kristen di Indonesia. Indonesian Journal of Theology, 7(1), 88-110.

Mudzakir, A. (2015, November). Dekolonisasi Sejarah Indonesia dalam Perspektif Poskolonial Belanda. In The Third Graduate Seminar of History, Universitas Gadjah Mada, Yogyakarta (pp. 3-4).

Oostindie, G. (2016). Serdadu Belanda di Indonesia 1945-1950. Translated by S. Moeimam, N. Santoso, and M. Sutedja-Liem. Jakarta: Yayasan Obor Indonesia.

Purwanto, B., \& Nursam, M. (2006). Gagalnya Historiografi Indonesiasentris?!. Yogyakarta: Ombak.

Rusdiyani, E. (2016). Pembentukan Karakter dan Moralitas Bagi Generasi Muda Yang Berpedoman Pada NilaiNilai Pancasila Serta Kearifan Lokal. Prosiding Seminar Nasional Pendidikan Kewarganegaraan 2016.

Saefudin, A. (2013). Analisis pembelajaran sejarah isu-isu kontroversial di SMA (Studi Kasus di SMA Negeri 1 Banyumas) (Doctoral dissertation, UNS (Sebelas Maret University)).

Sari, M., \& Asmendri, A. (2020). Penelitian Kepustakaan (Library Research) dalam Penelitian Pendidikan IPA. Natural Science: Jurnal Penelitian Bidang IPA Dan Pendidikan IPA, 6(1), 41-53.

Sayono, J. (2015). Pembelajaran Sejarah di Sekolah: Dari Pragmatis ke Idealis. Jurnal Sejarah dan Budaya, 7(1), 9-17.

Sirnayatin, T. A. (2017). Membangun Karakter Bangsa Melalui Pembelajaran Sejarah. SAP (Susunan Artikel Pendidikan), 1(3).

Sugiarti, Y. (2020). Indo sebagai "the self/ sang diri" versus Indo sebagai "the other/ sang lain" dalam Sastra dan Realita. 
Jurnal Integrasi dan Harmoni Inovatif Ilmu-Ilmu Sosial, 1(4), 2021, 425-436

Sulistiyono, S. T. (2016). "Historiografi Pembebasan": Suatu Alternatif. AGASTYA: JURNAL SEJARAH DAN PEMBELAJARANNYA, 6(01), 9-24.

Susanto, H. (2016). Kolonialisme dan Identitas Kebangsaan Negara-negara Asia Tenggara. Jurnal Sejarah dan Budaya, 10(2), 144-155.

Tjamboek, B. (2004). Indonesia Dalem Api dan Bara. Jakarta: Elkasa.

Ulhaq, Z. (2017). Pembelajaran Sejarah Berbasis Kurikulum 2013 di SMA Kotamadya Jakarta Timur. Jurnal Pendidikan Sejarah, 6(2), 49-60. 